Gut Festschrift, 1989, 17-21

\title{
William Hillary and sprue in the Caribbean: 230 years later
}

\author{
COURTENAY BARTHOLOMEW
}

Aretacus from Cappadocchia, which was at that time part of the Greek Empire and is now part of present day Turkey, left us an account of sprue in Chapter VII of his extant works entitled 'On the Coeliac Affection'.' This was in the second or third century AD and probably refers to coeliac sprue.

More than a millenium later, in 1747, an Englishman, more specifically a Yorkshireman, migrated to the Caribbean island of Barbados which had been a British colony since 1627. This Yorkshireman, Dr William Hillary, came to practice medicine but was also a systematic observer of the weather and its relationship to disease. He began these observations in Ripon in England and resumed them in Barbados. In 1759, he published one of the earliest books in the English medical literature on tropical diarrhoeal disease which occurred more frequently in native Barbadians than in white settlers. It carried the cumbersome title Observations on the changes of the air and the concomitant epidemical diseases in the Island of Barbadoes, to which is added a treatise on the putrid bilious fever, commonly called the yellow fever; and such other diseases as are indigenous or endemical in the West Indian Islands. ' This book was published by Hawes, Clarke, and Collins in London and a copy can still be found in the Barbados Museum.

In 1880, Manson" was probably the first to use the term 'sprue' for the wasting illness with diarrhoea occurring in some tropical countries. Apparently this is an anglicised version of the Dutch word 'sprouw' which Ketelaer' had given to a diarrhoeal disorder with aphthous ulceration occurring in Holland and which is now believed to be coeliac disease. Vincent Ketelaer was a Dutch physician who was rector of the Gymnasium of Zierikzsee. His treatise, De aapthis nostratibus seu Belgarum Sprouw (concerning native aphtha or sprue of the Belgians) first appeared in 1669 and was reprinted several times. It gave another very clear description of sprue but is differentiated from the clinically somewhat similar disease occurring in the tropics which was subsequently called 'tropical sprue'.

By the early part of this century, tropical sprue was also recognised in the Indian subcontinent, in Ceylon (Sri Lanka), in South East Asia and in islands of the
Caribbean other than Barbados. By now it was thought to be a disease which affected predominantly European and American expatriates living in the tropics and sparing the indigenous populations. On the other hand studies of native populations in South India, reported by Baker in 1951, showed that tropical sprue was not limited to expatriate residents. This has been confirmed by other investigators.

In more recent times, another Yorkshireman, Christopher Booth, kindled my interest in small bowel disease when I was a student at the Postgraduate Medical School at Hammersmith in 1963. Obtaining biopsies of small bowel mucosa had been pioneered by Shiner and Crosby and the dissecting microscope became to the gastroenterologist what the ophthalmoscope was to the ophthalmologist. As we peered through its lenses we enjoyed the slender beauty of normal finger-like villi, the brain-like convolutions of patients with the sprue syndrome and the denuded mosaic mucosa of those with severe coeliac disease as described by Holmes, Hourihane and Booth."

In those early days, Chris Booth would ask his students, 'If you had one test, and only one test, to make a diagnosis of coeliac disease, what would you choose?'. The answer he expected was 'a small bowel biopsy'. At that time it was thought that a flat mucosa was diagnostic of coeliac disease but regarding tropical sprue the situation was less clear. At the 1962 meeting of the CIBA Foundation Study Group on Intestinal Biopsy held in honour of Professor C Jimenez Diaz, professor of medicine in Madrid," Tom Hendrix of Johns Hopkins, Baltimore, asked Charlotte Andersen of the Royal Childrens Hospital, Melbourne, 'Have you seen a flat biopsy in any patients who do not respond to a gluten free diet?' To this she replied 'no, so far I have not seen a really flat biopsy in any other clinical situation'. Then Cyrus Rubin from Seattle commented '... while experience teaches that one cannot be dogmatic about such matters, at present it would appear that, with the exception of tropical sprue, the characteristic lesions are found only in coeliac disease and idiopathic steatorrhoea'. With the passage of time and tide, however, experience did teach us otherwise. On intestinal biopsies and tropical sprue Booth had this 


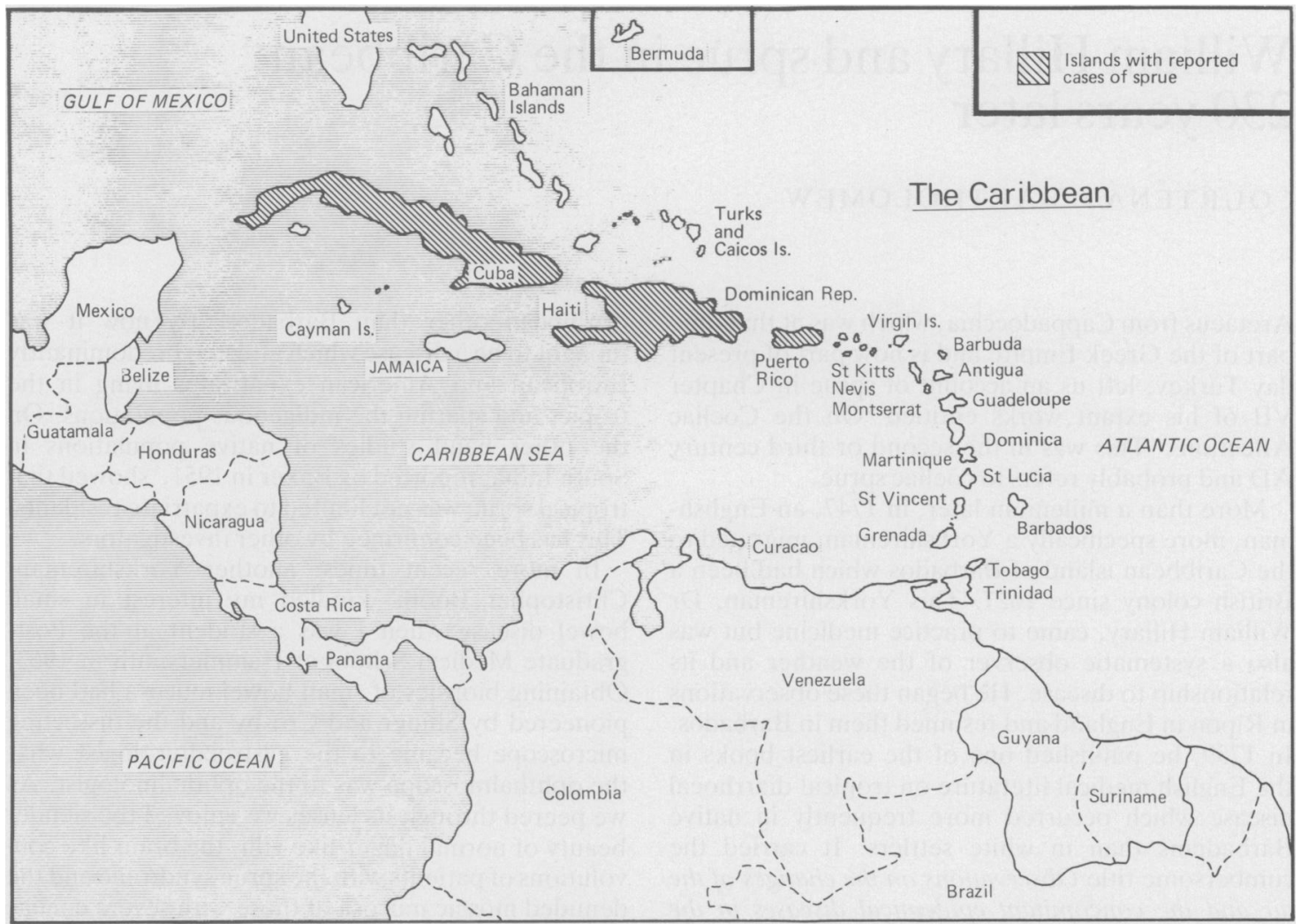

to say, 'In our studies of jejunal biopsies obtained from patients with tropical sprue we have never seen the flat appearance. The jejunal mucosa in these patients has invariably shown a convoluted appearance. There is no suggestion of a flat mosiac pattern...' With perhaps a rare exception this rule still holds true.

After leaving London I spent two years as Donner research fellow at the Royal Victoria Hospital, Montreal. This further whetted my appetite for the study of small bowel disease but in 1967, when I returned to a permanent position in Trinidad I found that sprue was rarely recognised in the Caribbean islands.

In 1970, Mike Ashcroft of the MRC Epidemiology Unit in the University of the West Indies recorded that E K Cruickshank (professor of medicine) had not seen a single case of tropical sprue in the period 1950-1970. ' Similarly, Banwell et al, ${ }^{89}$ Foy and Kondi, ${ }^{11}$ and Cook ${ }^{11}$ were unable to find tropical sprue in Africa. A W Woodruff in his textbook, Medicine in the tropics, speculated that 'Although tropical sprue occurs widely in the tropics this does not apply to Africa and its virtual non-occurrence in the people of that continent may indicate a genetic- ally determined difference in response to a hypothetical infection. The fact that African troops in Burma were not affected during World War II lends support to this view'. '2 On the other hand F Klipstein ${ }^{13}$ denied the presence of a racial factor because tropical sprue is common amongst persons of African descent living in Haiti. In 1970, Moshal et al ${ }^{4}$ from Durban reported that in the first 12 months after the establishment of a gastroenterology unit in the King Edward VIII hospital, eight cases of an illness resembling tropical sprue were seen amongst Africans and he concluded that the establishment of more specialist units in Africa would lead to more cases being found as well as a variety of diseases associated with secondary malabsorption.

Over the past 20 years several physicians with a special interest in gastroenterology have been appointed to hospitals in the Caribbean. Yet up to this year, 230 years after Hillary's publication, not a single case of tropical sprue has been documented in Trinidad and Tobago, neither in expatriates here, nor in those who have returned to their original homes, nor in the indigenous population. The same applies to the other English speaking Caribbean islands, including Barbados (C Edwards, personal 


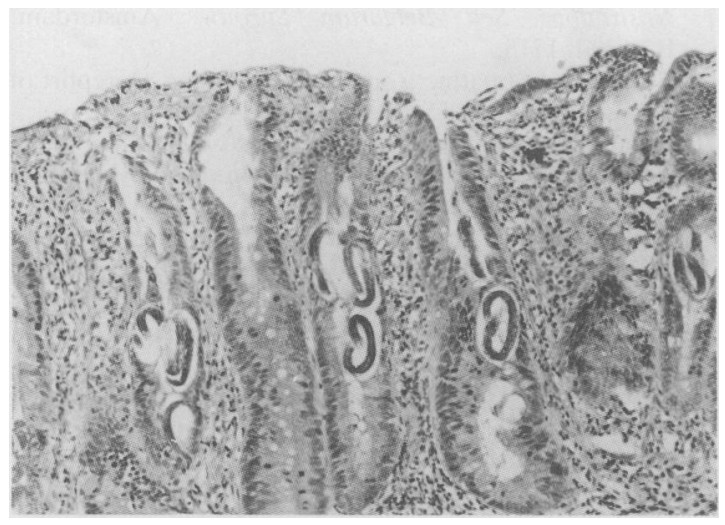

Fig. 1 Histology of jejunal mucosa of the flat type showing $\mathrm{S}$ stercorales in the crypts.

communication 1989). It is remarkable that we are unable to find any document recording the history of the decline of tropical sprue in Barbados. In contrast, studies by Rodriguez-Molina, ${ }^{15}$ Milanes, ${ }^{16}$ and Sheehy et al ${ }^{17}$ have shown evidence that the incidence of tropical sprue has declined in Puerto Rico and Cuba, but it is said to have remained widespread among the rural population in Haiti. An explanation is certainly needed to account for the present restriction of sprue to the Spanish and French speaking Caribbean islands (Cuba, Puerto Rico, the Dominican Republic, and Haiti) and its absence from the English speaking Commonwealth chain of islands from Jamaica in the north to Trinidad and Tobago farthest south.

The patchy occurrence of tropical sprue in the Tropics also remains unexplained and indeed after years of extensive research the aetiology of tropical sprue remains elusive. Its restriction to the Tropics suggests that an infectious agent may be involved but despite many efforts none has been identified neither by culture nor by direct observation through the electron microscope. A viral aetiology remains a possibility. ${ }^{1 x}$ I would remind you that in the West Indies we had a similar problem with the aetiology of tropical spastic paraparesis. ${ }^{19}$ It was not until 1986 that a type $\mathrm{C}$ retrovirus (the human T-cell leukemia/ lymphoma virus, HTLV-I) was found to be associated with this tropical syndrome.

The absence of sprue in the English speaking Caribbean is not restricted to the tropical variety. Coeliac sprue is also rarely seen. For example, since 1967, only one case of adult coeliac disease has been recognised in Trinidad and Tobago and that was in a Trinidadian with Caucasian ancestry. Similarly coeliac sprue is rare in Africa. ${ }^{21}$ On the other hand lactase deficiency is common and in studying this

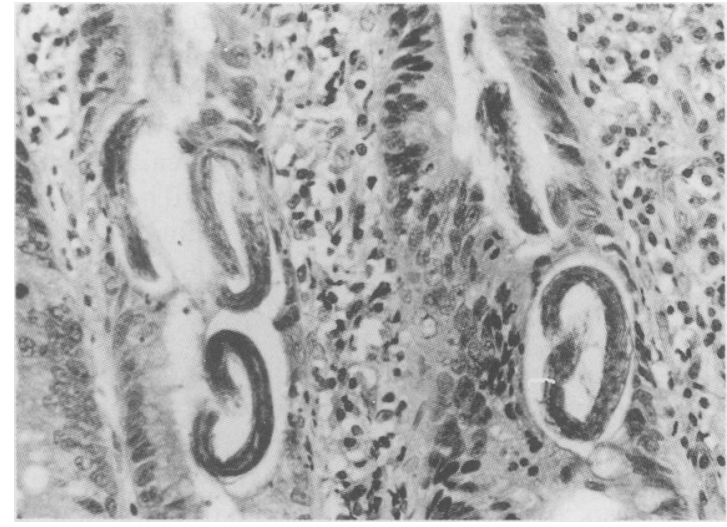

Fig. 2 Higher magnification of jejunal mucosa showing $\mathrm{S}$ strongyloides curled in crypts.

condition $^{21}$ we first recognised cases of a sprue-like syndrome in patients with chronic diarrhoea, peripheral oedema, marked weight loss, anaemia, and hypoproteinaemia. ${ }^{22}$ In one case the mucosa was flat when viewed through the dissecting microscope. In 1963, we would have thought this to be a case of adult coeliac disease. Through the light microscope, however, there was not only subtotal villous atrophy as seen in coeliac disease but also numerous ova and adult forms of strongyloides stercoralis lying curled up in the crypts of Lieberkuhn (Figs 1 and 2).

Parasitic infestation as a cause of diarrhoea and malabsorption is well recognised. It may occur in heavy infestations with hookworm as reported by Sheehy in Puerto Rico ${ }^{23}$ and with Giardia lamblia as reported by Professor O'Donovan of Dublin. ${ }^{24}$ In hookworm and giardial infestations tissue invasion of the small intestine has been observed occasionally ${ }^{25}$ but Strongyloides stercoralis has much greater potential in this respect. A sprue-like syndrome caused by this parasite is not uncommon in the Caribbean islands, particularly in Jamaica, ${ }^{26}$ Trinidad and Tobago, ${ }^{22}$ and Puerto Rico. ${ }^{27}$ Under the light microscope the mucosal surface may appear normal but more often there is partial villous atrophy. Our observations show that occasionally there is complete flattening of the mucosa and so strongyloidiasis must be added to the ever increasing list of diseases which cause subtotal villous atrophy. The inflammatory response in the interstitial mucosa is characterised by a local eosinophilia and an increased number of plasma cells. Sometimes filariform larvae may be found in the enlarged mesenteric nodes and the sinuses may be packed with macrophages, polymorphonuclear neutrophils and a few eosinophils.

Radiological studies in strongyloidiasis have also shown a sprue-like pattern. ${ }^{28}$ In the Trinidad 
series, three patients with heavy infestation with strongyloides were subjected to laparotomies after a mistaken diagnosis of partial small bowel obstruction and at operation there were dilated loops of jejunum without evidence of mechanical obstruction. The mesenteric nodes were enlarged in all these cases. Thus the clinical picture may mimic sprue as abdominal colic and episodes of pseudo-obstruction may occur in tropical and non-tropical varieties..$^{29}$ Fone $e a^{30} l^{30}$ reported that in 12 patients with coeliac sprue, five had colicky abdominal pains leading to laparotomy in two cases. In both these patients the small bowel was oedematous and the mesenteric lymph nodes were enlarged. Baker and Mathan ${ }^{31}$ have also observed that abdominal colic and a dilated small intestine have resulted in erroneous laparotomy in cases of tropical sprue.

Thus 230 years after Hillary's treatise on sprue in Barbados, the scene has changed and in West Indian immigrants to the United Kingdom a sprue-like syndrome is more likely to be the result of infestation with Strongyloides than to tropical sprue. This may not be true for immigrants from the Latin Caribbean islands.

I wish to thank Dr Graham Neale for inviting me to contribute to this festschrift in honour of Sir Christopher Booth. I also wish to thank Dr Farley Cleghorn for assisting me in the preparation of this manuscript and Dr Henry Fraser for procuring for me a copy of William Hillary's book from the Barbados Museum.

\section{University of the West Indies \\ and the \\ General Hospital, \\ Port of Spain, \\ Trinidad}

\section{References}

1 The extant works of Arataeus, the Cappadocchian. Edited and translated by Francis Adams, LLD. London: Sydenham Society, 1856.

2 Hillary W. Observations on the changes of the air and the concomitant epidemical diseases in the Island of Barbadoes, to which is added a treatise on the putrid bilious fever, commonly called the yellow fever; and such other diseases as are indigenous or endemical in the West Indian Islands. London: Hawes, Clarke and Collins, 1759.

3 Manson P. Notes on spruc. In: China, Imperial Maritime Customs, Special Series No. 2, Medical Reports for the Half-Year Ended 31st March, 1880. (19th issuc). Shanghai: Statistical Department of the Inspectorate General, 1880: 33-7.

4 Ketelacr V. Commentarius Medicus de Apthis
Nostratibus Seu Belgarum Sproun: Amsterdam: Bernard, 1715.

5 Baker SJ. Idiopathic tropical steatorrhoca. A report of 60 cases. Ind J Med Sci 1957; 11: 687-9.

6 Ciba Foundation Study Group no. 14. Wolstenholme GEW, Cameron MP, cds. Intestinal biopsy. Edinburgh: Churchill, Livingstone, 1962.

7 Ashcroft MT. Tropical sprue in the Caribbean. Lancet 1970; ii: 724-5.

8 Banwell JG, Hutt MRS, Marsden PD, Blackman V. Malabsorption syndromes among African people in Uganda. East Afr Med J 1967; 41: 188-93.

9 Banwell JG, Hutt MSR, Leonard PJ, et al. Exocrinc pancreatic disease and the malabsorption syndrome in tropical Africa. Gut 1964; 8: 388-401.

10 Foy H. Kondi A. Megaloblastic anaemia in East Africa. In: Tropical sprue and megaloblastic anaemia. Wellcome Trust Colaborative Study. Wellcome Trust. Edinburgh, London: Churchill Livingstone. 1971: 261-8.

11 Cook GC. Malabsorption in Africa. Trans $R$ Soc Trop Med Hyg 1974; 68: 419-35.

12 Woodruff AW, ed. Medicine in the Tropics. Edinburgh and London: Churchill Livingstone. 1974.

13 Klipstein F. Tropical sprue. In: Bockus HL. ed. (jastroenterology: Vol II. Philadelphia, London. and Toronto: WB Saunders, 1976.

14 Moshal MG, Hift W, Kallichurum S, Pillay K. Endemic tropical spruc in Africa. J Trop Med Hyg 1975: 78: 2-5.

15 Rodriquez-Molina R. Spruc in Pucrto Rico: 10 years later. Puerto Rico J Public Health Trop Med 1943: 18: 314-40.

16 Milanes F. Changes in the epidemiology and clinical features of sprue in Cuba between 1927 and 1957. Arch Hosp Univ HABANA 1960; 12: 125-36.

17 Sheehy TW, Cohen WC, Wallace DK. Legters LJ. Tropical sprue in North Americans. JAMA 1965: 194: 1069-76.

18 Baker SJ. Idiopathic small intestinal diseases in the tropics. In: Chandra RK, ed. Critical reviews in tropical medicine. New York and London: Plenum Press. 1982.

19 Rodgers PEB. The clinical features and actiology of the neuropathic syndrome in Jamaica. W I Med J 1965: 36: $36-47$.

20) Trowell HC. Jelliffe DB. Diseases of children in the subtropics and tropics. London: Arnold, 1958.

21 Bartholomew C. Young Pong O. Lactose intolerance in East Indians of Trinidad. Trop Geog Med 1976: 28: 336-38.

22 Bartholomew C. Butler AK, Bhaskar AG, Jankey N. Pscudo-Obstruction and a sprue-like syndrome from strongyloidiasis. Postgrad Med J 1977: 53: 139-12.

23 Sheehy TW. Meroney WH. Cox RS. Soler JE. Hookworm discase and malabsorption. Gastroenterology 1962; 42: 148-50.

24 O`Donovan DK. McGrath J, Bolan SJ. Giardial infestation with steatorrhoca. Lancet 1942; ii: 4-5.

25 Brandborg LL. Tankersley CB. Gottlieb S. Barancik M. Sartor BE. Histological demonstration on mucosal invasion by Giardia lamblia in man. Gastroenterology 1967; 52: 143-5.

26 Bras G, Richards RC. Irvine RA. Miner PFA, Ragbir 
MMS. Infection with Strongyloides stercorales in Jamaica. Lancet 1964; ii: 1257-8.

27 Rivera E. Maldonado N, Velez-Garcia E, Grillo AJ, Mallaret G. Hyperinfection with Strongyloides stercorales. Ann Intern Med 1970; 72: 199-201.

28 Patterson DE. Strongyloides infestation of jejunum. Br J Radiol 1958; 31: 102-4.

29 Badenoch J. Steatorrhoca in the adult. Br Med J 1960; ii:
879-81.

30 Fone DJ, Cooke WT, Maynell MJ, et al. Jejunal biopsy in adult cocliac disease and allicd disorders. Lancet 1960; i: 933-5.

31 Baker SJ, Mathan VI. In: Tropical sprue and megaloblastic anemia. Wellcome Trust Collaborative Study, Wellcome Trust. Edinburgh and London: Churchill Livingstone, 1971. 